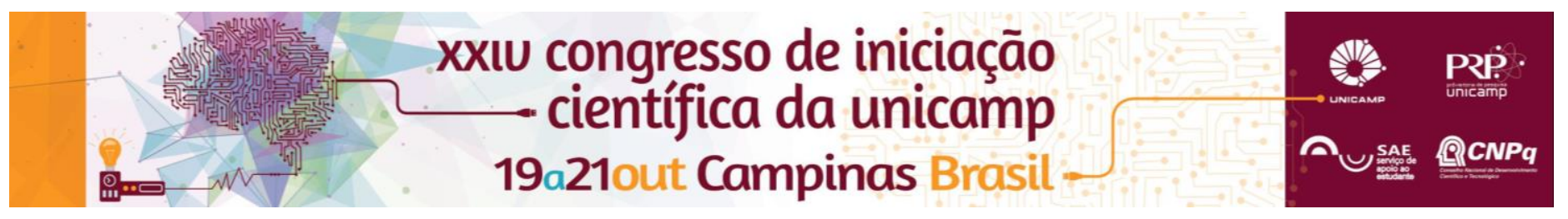

\title{
Concentração Fundiária e Distribuição de Renda na Região Norte
}

\author{
Bruno C. C. Medeiros ${ }^{\star}$, Alexandre Gori Maia, Gisele E. A. B. Souza.
}

\section{Resumo}

O objetivo dessa peqsuisa é verificar se a concentração fundiária na região Norte tem aumentado nos últimos anos e se isso se reflete em uma maior concentração da renda e da produção. Para tanto, foi descrita a dinâmica da concentração de terra (por décimos de tamanho do estabelecimento) e da renda na região. Além disso, também foram verificados os diferentes componentes da renda (trabalho e transferências), para destacar que os benefícios sociais podem estar atenuando os impactos da maior concentração da renda do trabalho. Para a execução do projeto, foram utilizados dados da PNAD/IBGE, trabalhado pelo programa estatístico Statistical Analysis System (SAS).Os resultados da região Norte são comparados com os do restante do país.

Palavras-chave: Concentração Fundiária, Renda, Região Norte

\section{Introdução}

Este estudo tem como objetivo: (i) analisar a dinâmica da concentração fundiária na região Norte e suas associações com a concentração de renda, e (ii) analisar a contribuição da renda do trabalho, aposentadoria e outras fontes sobre a concentração de renda entre empreendimentos relativamente ricos e pobres. Especificamente, busca-se, primeiro, analisar o total e \% do número e da área dos empreendimentos agrícolas por grupo de área total ao longo do período. Segundo, pretende-se comparar a dinâmica da renda média domiciliar e \% da renda domiciliar total por grupos de área. Por fim, pretende-se analisar o comportamento da distribuição da renda média do trabalho, aposentadorias e pensões e outras fontes dos empreendimentos agrícolas, por centésimos de renda, no mesmo período.

\section{Resultados e Discussão}

Fig.1 - Razão de concentração dos empreend. agrícolas com área $<10$ ha e $>100$ ha, Brasil (excluindo Norte) e Norte - 2004 a 2014

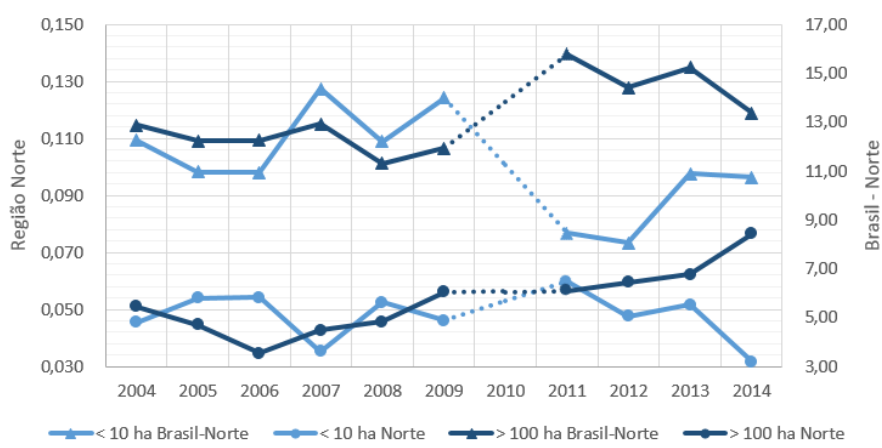

Fig. 2 - Variação dos Índices de Gini da distribuição da área dos empreend. agrícolas de 0,1 a menos de 10.000 hectares, Brasil (exceto Norte) e Norte - 2004 a 2014

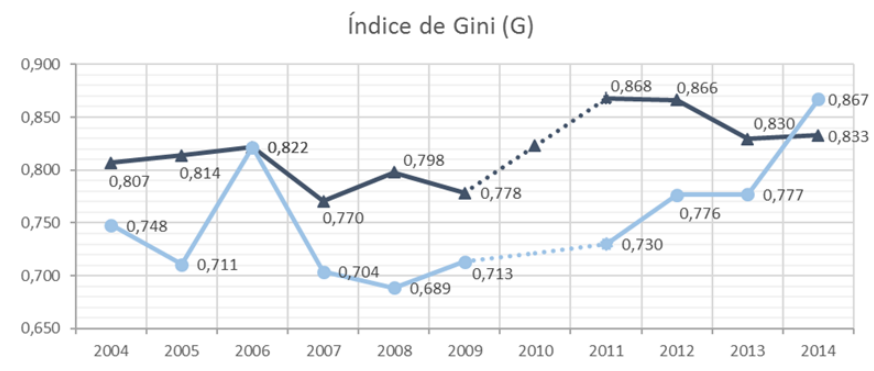

Fig. 3 - Razão de concentração da renda dos empreend. agrícolas com área $<10$ ha e >100 ha, Norte - 2004 a 2014

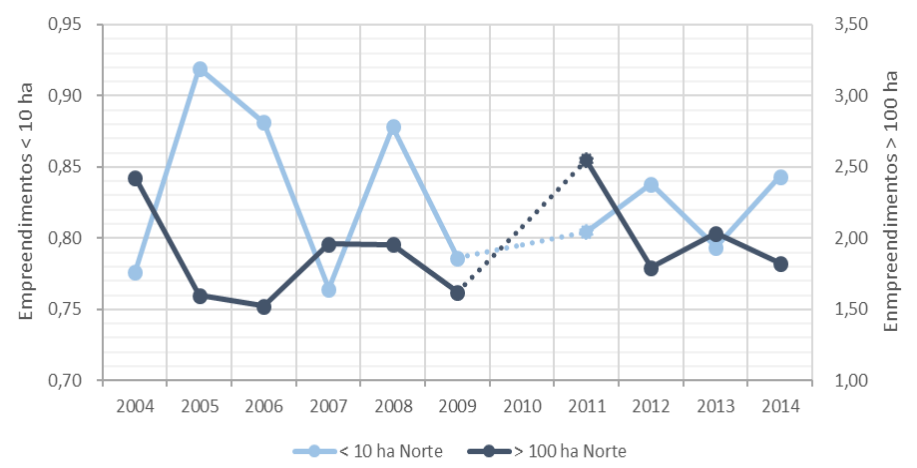

\section{Conclusões}

No período 2004-2014, houve um aprofundamento da já elevada concentração de terra na região Norte, em dinâmica oposta à observada no Brasil. Tanto no Brasil quanto no Norte, os pequenos empreendimentos passaram a ter maior concentração de renda, enquanto que nos grandes empreendimentos a concentração de renda reduziu. Porém, na Região Norte os efeitos foram mais intensos. Na região Norte, o incremento da renda nos grupos com área até 10 ha e de 10 a 100 ha, foi determinado em primeiro lugar pela renda de outras fontes, seguida por aposentadorias e pensões $e$ finalmente pela renda do trabalho. Porém, diferente da tendência no Brasil, os empreendimentos com área superior a 100 ha na região Norte também tiveram como fonte de renda mais determinante as outras fontes, seguida de aposentadorias e pensões e renda do trabalho. Na verdade o que se observa é que os empreendimentos agrícolas do Norte têm renda muito baixa e, portanto, a renda de outras fontes, provavelmente do Bolsa Família tem uma grande importância para o incremento da renda das famílias, embora não seja a mais significativa na composição da renda total de cada grupo de área, até porque essa fonte de renda é regida por limites legais.

\section{Referências}

HOFFMANN, Rodolfo \& NEY, Marlon Gomes. Estrutura fundiária e propriedade agrícola no Brasil: grandes regiões e unidades da federação. Brasília: Ministério do Desenvolvimento Agrário, 2010. 108p. 